\title{
The Effect of Tangkil Flakers Changes Against Hand Pain in Emping Industry Workers in Banten
}

\author{
Maria Eka Putri \\ Department of Occupational Health and Safety \\ Faculty of Medicine and Health, University of Muhammadiyah Jakarta \\ Jakarta, Indonesia
}

\begin{abstract}
The position of work and tools that are not appropriate can cause a pain. In emping workers, many complained about musculoskeletal disorders in the form of hand pain. A very simple hammer tool was still used in emping maker. This study aims to examine the effect of tangkil flakers changes on hand pain. This study was using quasi-design experiments of one group pre and post test, using the intervention of the pitcher in the form of pestle and performed on 31 emping workers. Data collection was done by interview, physical examination and observation. The inclusion criteria was a worker with working period $\geq 1$ year and willing to be a respondent by signing informed consent, the exclusion criteria was having a history of rheumatoid arthritis disease, having congenital abnormalities on the hands, being on pain reliever and having fracture on hand. The results showed a decrease in the scale of hand pain after intervention for 14 days at $93.5 \%$. There was a significant difference in the scale of hand pain before and after intervention with pestle as a new tangkil flakers by $p$ value $=0.000$. The hypothesis proved that there was a decrease of hand pain after intervention with pestle for 14 days compared to before intervention $(p=0.000: 95 \% \mathrm{CI}=1.07-1.72)$. The prevalence of hand pain in emping workers was $82 \%$.
\end{abstract}

Keywords - hand pain; pestle; VAS

\section{INTRODUCTION}

The inadequate availability of formal sector employment in accommodating the number of workers in Indonesia were able to open the inspiration of the villagers, especially in Banten to open an informal sector business of emping chips which was also able to absorb labor and generate income and even foreign exchange for the country. Determination of emping chips as a Pandeglang's special food in 2009, trigger desire of community in Pandeglang village in an attempt to produce emping chips as a household industry that was able to increase supplement income. The growth of emping business in Banten was very fast, in 2008 the number of entrepreneurs only recorded 1.141 people and in 2009 has reached 1300 people. However, the large number of informal sector workers has not been fully addressed in terms of occupational health and safety [1-3].
Workers in an informal sector in Indonesia were mostly still using manual methods. Manually working with old static positions, repetitive movements and unsuitable work tools had a negative impact on workers, resulting in musculoskeletal disorders such as pain in the hands. This was certainly affect the process, production and income [4].

Based on WHO report at 2003, musculoskeletal disorder is the most common occupational disease and estimated for $60 \%$ of all occupational diseases [5].

According to the Indonesian Department of Health at 2005, work health-related were quite large by $40.5 \%$. Among the complaints were musculoskeletal disorders due to work as much as $16 \%$ [6].

Earlier studies by Woro, 2008 mentioned the results of a study involving 800 people from 8 informal sectors in Indonesia showed that musculoskeletal disorders on the wrist, shoulder and back were most complained about. Lusianawaty Tana, 2009 mentions that skeletal muscle disorders in the upper limb of female garment workers by $59.9 \%$. Sim J et al, 2006 reported the prevalence of upper extremity pain in the general adult population in North Staffordshire by $44 \%[7,8]$.

Hand pain due to the way of work position and work tools that are not appropriate can cause pain. It was necessary to design the work tool and the appropriate way of working so that hand pain problems can be overcome.

The production process of emping chips was done manually, using a simply flakers shaped hammer tool made of iron and wood. The production process by repetitive motions, static work positions by gripping these very simple tools and work tools can lead to work-related musculoskeletal disorders by health perspective. Based on background survey results conducted on emping workers in Banten obtained pain complaints on the hands by $84 \%$. In order for the process, yield and income from the production of emping was not experiencing barriers then it is necessary to make a way so that hand pain can be overcome.

To reduce complaints of hand pain, one way that can be done was design a suitable and comfortable flakers tools for workers. By interfering with the using of flakers, it was expected to decrease hand pain. So the research on the 
comparison of hand pain before and after treatment at industrial emping workers in Banten province can be known.

\section{METHODS}

The research used Quasi Experimental design of one group pre-post test. The subjects were subjected to fourteen days of intervention in the use of a new tangkil flakers tools.

\begin{tabular}{|l|c|l|}
\hline Pre Test & \multirow{2}{*}{$\begin{array}{c}\text { X } \\
\text { OH }\end{array}$} & Post Test \\
\cline { 1 - 1 } & "HAMER" 2 \\
\hline
\end{tabular}

O1: pre test: before intervention

O2: post test: after intervention

$\mathrm{X}$ : Intervention: Provision of new tangkil flakers.

\section{A. Sample size}

The samples size was calculated based on the Slovin formula, 2005:

$$
\mathrm{n}=\frac{\mathrm{N}}{1+\mathrm{N}(\mathrm{D})^{2}}
$$

Information:

$\mathrm{N}=$ Number of samples

$\mathrm{N}=$ emping workers population $=41$ (survey results Introduction)

$\mathrm{D}=$ desired level of trust $=0.1$

The sample of research were 30 people who have fulfilled inclusion and exclusion criteria. Overall sample size after added drop out $10 \%$ were 33 people. 50 people of emping industry workers population in Cikuasa village, Banten was selected according to inclusion and exclusion criteria by using questionnaire. The result of the election was obtained 41 people suffering from hand pain. Based on the formula of sample calculation, the number of samples were 33 people. To determine the 33 people of the sample was done by simple random sampling.

\section{RESULTS}

Table 1 shows the distribution of sociodemographic characteristics. After the normality test with Shapiro Wilk obtained $\mathrm{p}$ value for age: 0,145 , indicating that the data was normally distributed. The age of most emping industry workers was $<45$ years $(58.1 \%)$ with a mean of 41 years. Workers of emping industry with low education are higher than those with high education which is $87.1 \%$. Most $(90.3 \%)$ emping workers did not exercise and $77.4 \%$ did not receive job training in the emping industry.
TABLE I

DISTRIBUTION OF SOCIODEMOGRAPHIC CHARACTERISTICS

\begin{tabular}{|l|c|c|}
\hline & $\begin{array}{c}\text { Frequency } \\
\text { n=31 }\end{array}$ & $\%$ \\
\hline Age & & \\
\hline$\geq 45$ years & 13 & 41.9 \\
\hline$<45$ years & 18 & 58.1 \\
\hline Education & & \\
\hline Low & 27 & 87.1 \\
\hline High & 4 & 12.9 \\
\hline Exercise & & \\
\hline No & 28 & 90.3 \\
\hline Yes & 3 & 9.7 \\
\hline Training & 24 & 77.4 \\
\hline No & 7 & 22.6 \\
\hline Yes & & \\
\hline
\end{tabular}

\section{A. Respondent's Job Characteristics}

Table 2 shows the distribution of job characteristics. After the normality test with Shapiro Wilk obtained the length of work, the working period is not normally distributed $(\mathrm{p}=0.04$ and $\mathrm{p}=0.027$ ). As many as $80.6 \%$ have a working period $\geq 40$ hours / week with a mean of 48 hours. Period of $>10$ years of $45.2 \%$, with a mean of 13 years.

TABLE II.

RESPONDENT'S JOB CHARACTERISTICS

\begin{tabular}{|l|c|c|}
\hline & $\begin{array}{c}\text { Frequency } \\
\mathbf{n = 3 1}\end{array}$ & $\mathbf{\%}$ \\
\hline Working Duration & & \\
\hline$>40$ hours/week & 25 & 80.6 \\
\hline 40 hours/week & 6 & 19.4 \\
\hline Working Years & & \\
\hline$>10$ years & 14 & 45.2 \\
\hline $1-10$ years & 17 & 54.8 \\
\hline
\end{tabular}

\section{B. Measurement Results Before and After Intervention In} Pain Category, Complaint Type and Frequency of Repetitive Movement

Table 3 shows the proportion of measurement results before and after the intervention in the pain category, type of complaint and frequency of repetitive movement. From VAS measurements of pre intervention the proportion of moderate and severe pain was $96.8 \%$, after moderate and severe complaints intervention decreased to $67.8 \%$. Before the intervention there was a severe pain complaint, but after the intervention the severe pain complaint became non-existent. As for mild pain complaints after intervention increased by $29 \%$. 
TABLE III.

PROPORTION OF MEASUREMENT RESUlTS BEFORE AND AFTER INTERVENTION IN PAIN CATEGORY, COMPLAINT TYPE AND FREQUENCY OF REPETITIVE MOVEMENT

\begin{tabular}{|c|c|c|c|c|c|}
\hline & & \multicolumn{2}{|c|}{$\begin{array}{c}\text { Before } \\
\text { Intervention }\end{array}$} & \multicolumn{2}{|c|}{$\begin{array}{c}\text { After } \\
\text { Intervention }\end{array}$} \\
\hline & & $\mathbf{N}$ & $\%$ & $\mathbf{N}$ & $\%$ \\
\hline VAS Range & Pain Category & & & & \\
\hline $\mathbf{0}$ & No Pain & 0 & 0 & 0 & 0 \\
\hline $1-3$ & Mild Pain & 1 & 3.2 & 10 & 32.2 \\
\hline $4-6$ & Moderate Pain & 27 & 87.1 & 21 & 67.8 \\
\hline 7-9 & Severe Pain & 3 & 9.7 & 0 & 0 \\
\hline 10 & $\begin{array}{c}\text { Very Severe } \\
\text { Pain }\end{array}$ & 0 & 0 & 0 & 0 \\
\hline \multicolumn{6}{|c|}{ Complaint Type } \\
\hline \multicolumn{2}{|l|}{ Oedema } & $\mathbf{0}$ & $\mathbf{0}$ & $\mathbf{0}$ & $\mathbf{0}$ \\
\hline Redness & & 0 & 0 & 0 & 0 \\
\hline Stiffness & & 0 & 0 & 0 & 0 \\
\hline \multicolumn{6}{|c|}{ Frequency of Repetitive Movement } \\
\hline \multicolumn{2}{|l|}{$\leq 1200 \mathrm{x} /$ hour } & 0 & 0 & 0 & 0 \\
\hline \multicolumn{2}{|c|}{$2000-\leq 4000 \times /$ hour } & 0 & 0 & 11 & 35.5 \\
\hline \multicolumn{2}{|c|}{$4001-\leq 6000 x /$ hour } & 19 & 61.2 & 16 & 51.6 \\
\hline \multicolumn{2}{|c|}{$6001-8000 x /$ hour } & 12 & 38.8 & 4 & 12.9 \\
\hline \multicolumn{6}{|c|}{ Pain Location } \\
\hline Fingers & & 4 & 3.2 & 6 & 19.3 \\
\hline Palm & & 20 & 64.5 & 25 & 80.6 \\
\hline Wrist & & 7 & 22.5 & 0 & 0 \\
\hline
\end{tabular}

The most common type of complaint prior to the intervention was stiffness of the fingers of $9.6 \%$, after intervention no longer found complaints of stiffness, edema or redness.

It can also be seen on the table 3 , the frequency of repetitive movement between $4000-8000$ x / hour by $100 \%$, after intervention decreased to $64.5 \%$. Before the frequency intervention of repetitive movement $2000-\leq 4000 \mathrm{x} /$ hour was not found, after intervention by $35.5 \%$. For repetitive motion frequency $\leq 1200 \mathrm{x}$ /hour before and after intervention not found.

Before the intervention there was a pain complaint on the wrist at $22.5 \%$, after the intervention grievance at the location became absent. The location of pain in the palms and fingers before intervention was $64.5 \%$ and $3.2 \%$, after intervention increased to $80.6 \%$ for the palms and $19.3 \%$ for the fingers.

From Table 3, it can be seen that there was only a change of category of pain before the initially severe painful intervention became moderate pain, and the former pain was being rigid, but did not relieve the pain suffered. The cause was due to suffered chronic pain. Based on the theory, acute pain relief process lasts for 2 weeks, while for chronic pain it takes longer recovery time.

The most common type of complaint before intervention was stiffness $(9.6 \%)$. After the intervention there are no more complaints. This is due to the working position that changes from the extension flexion $\geq 20^{\circ}$ to $0^{\circ}$. On $0^{\circ}$ hand position does not occur excessive hand muscle contraction that can cause stiffness.

Table 3 also shows the frequency of repetitive movement after intervention has decreased compared to before the intervention, although the decrease has not reached the normal value allowed for repetitive movement, since it still ranges from 2000 to $8000 \mathrm{x} /$ hour. This can be explained because from the beginning (before the intervention) the frequency of repetitive movement that occurred has exceeded the normal limits that should $(<1200 \mathrm{x} /$ hour $)$. In addition, the work process to flakers the tangkil by hammering pestle on the tangkil become emping until thinness enough, must be done repeatedly, because the raw material of emping (tangkil) was thick enough.

The location of pain before the intervention strikes the wrist by $22.5 \%$, but after intervention decreases to $6.45 \%$. It can be explained due to the lack of flexion wrist extension after using pestle then the excessive muscle contraction become reduced and the complaints of pain disappear. While the pain complaints in the palms and fingers increased after using pestle, this is due to the static position of grasping the flipper for a long time.

\section{Hand Pain Scale Measurement Before and After Intervention}

During the intervention period using pestle for 14 days, hand pain measurements with Visual Analog Scale (VAS) with a range of values between 0 - 10 were performed 3 times at (1) one day before the intervention (pre intervention), (2) Seventh day after the intervention $(D+7),(30)$ fourteenth day after intervention (post intervention).

Table 4 showed the results of hand-pain scale measurements before and after interventions, it showed a decrease in the average scale of hand pain starting at D +7 interventions (4.46 out of 4.97). Greater mean decrease in post intervention (3.57 out of 4.46). The difference in mean of hand pain in pre intervention compared to post intervention was 1.4.

Table 5 showed the change in the proportion of the scale of hand pain after intervention. After fourteen-day intervention, the proportion of hand-pain scales decreased by $93.5 \%$. The VAS decrease scale was categorized down if on VAS measurement at 14 day intervention (post intervention) there was a decrease of $\geq 0.5 \mathrm{~cm}$ from scale compared with previous VAS value.

TABLE IV.

HAND PAIN SCALE MEASUREMENT BEFORE AND AFTER INTERVENTION TABLE STYLES

\begin{tabular}{|c|l|l|l|l|}
\hline & Mean & Min & Max & Med \\
\hline Pre Intervention & 4.97 & 3.0 & 6.9 & 5.0 \\
\hline Intervention D+7 & 4.46 & 2.5 & 6.9 & 4.2 \\
\hline Intervention D+14 & 3.57 & 2.2 & 5.8 & 3.5 \\
\hline$\Delta$ Pre and D+14 & 1.4 & & & \\
\hline
\end{tabular}

TABLE V. Proportion of HAND PAin Scale Changes AFTER INTERVENTION

\begin{tabular}{|l|l|l|}
\hline & $\mathbf{n = 3 1}$ & $\mathbf{\%}$ \\
\hline Constant & 2 & 6.5 \\
\hline Descend & 29 & 93.5 \\
\hline
\end{tabular}




\section{Research Hypothesis}

The hypothesis of this study was the decrease of hand pain scale after getting intervention using pestle compared with before the use of pestle for fourteen days. To prove it, used the paired t test.

Table 6 showed a significant difference $\mathrm{p}=0.00(95 \% \mathrm{C}=$ $1.075-1.724)$ after intervention for fourteen days.

TABLE VI. Hypothesis TeSt in HAND PAIN SCALE CHANGES

\begin{tabular}{|l|c|c|c|c|}
\hline & Mean & SD & $\mathbf{9 5 \%}$ CI & $\begin{array}{c}\mathbf{p} \\
\text { Paired t-test }\end{array}$ \\
\hline Pre \& H+14 & 1.4 & 0.885 & $1.07-1.72$ & 0.00 \\
\hline Pre \& H+7 & 0.01 & 0.143 & $0.77-0.75$ & 0.97 \\
\hline $\mathrm{H}+7$ \& +14 & 1.22 & 1.095 & $0.64-1.80$ & 0.00 \\
\hline
\end{tabular}

The manually production process of emping was done by simple work tool that was much use of hand with unstable body position (wrist flexion extension $\geq 20^{\circ}$ ) and repetitive movement and heavy equipment load, theoretically can lead to the emergence hand trauma due to mechanical trauma repetition. To eliminate the risk of hand pain, there must be made changes the tool from the "hammer" to "pestle" where the pestle weight has a slight reduction from 900 to 1000 grams to 800 - 850 grams. Using a pestle during the tangkil hammering, the wrist flexion-extension movement from $\geq 20^{\circ}$ to $0^{\circ}$, and the frequency of repetitive movement decreased from before, although the decrease in frequency has not reached the normal value $(>2000 \mathrm{x} / \mathrm{h}$ ). Changes in wrist extension flexion position, repetitive motion frequency as well as device weight affect the VAS decline after intervention.

In accordance with table 6 , found the statistical test results $(p=0.00,95 \% \mathrm{CI}=1.07-1.72)$, this data states the results of research in accordance with the hypothesis that there was a decrease in the scale of hand pain after using pestle, the tangkil flakers for fourteen days. With a mean of 1.4. This statistically showed a significant result, this was reinforced with the results of the research in Table 6, where there was a proportion of hand pain reduction in the study subjects of $93.5 \%$. But clinically a decrease of 0.5 scales from the VAS scale does not give significance to hand pain changes. It can be seen in Table 3 that after using the pestle, there were no respondents who stated no more pain. All respondents still feel hand pain, only a decrease in the degree of pain, this was because the pain suffered was chronic pain, while research time is only 2 weeks theoretically significant for acute pain changes. This explanation can also explain why the decrease in the scale of hand pain was seen on the 7 th and 14th interventions (Table 4).

Viewed from table 5 there were 2 respondents who did not experience a decrease in the pain scale, the chances of the respondent suffering chronic pain for a long time or suffering from CTS, so after the use of pestle for 2 weeks, the pain remained unchanged.

Therefore, there is a need for further research to examine the things that have not been studied in this study, such as reducing the frequency of repetitive movement in order to achieve the frequency (1200 x/hour).

The results of this study when associated with the results of emping production per day did not decrease. The resulting production remains the same, as much as $5 \mathrm{~kg}$ of tangkil produce $\pm 3 \mathrm{~kg}$ of chips. So in terms of productivity, this pestle can be used.

\section{E. Factors Correlation}

Table 7 showed the correlation between risk factors and the scale of hand pain changes. The statistical test showed that there was no significant correlation between the risk factors and the scale of hand pain changes

The results showed a meaningless association between age and decreased scale of hand pain. Although statistically not significant but when seen the percentage of hand pain decrease at age $\geq 45$ years bigger when compared with age $<45$ years. The probable cause of statistically significant association was the age of fewer $\geq 45$ workers $(41.9 \%)$, according to the theory that the higher the age the more the risk factor for hand pain. According to Table 7, the level of education shows a meaningless correlation with the scale of hand pain reduction. Low levels of education were more dominant $(87.1 \%)$ compared to the level of higher education, according to the theory the lower the level of education will be more difficult to make education for behavioral changes towards workers.

TABLE VII. CORRELATION BETWEEN RISK FACTORS AND THE SCALE OF HAND PAIN CHANGES AFTER INTERVENTION

\begin{tabular}{|c|c|c|c|c|c|}
\hline & \multicolumn{2}{|c|}{ Scale of Hand Pain } & \multirow{3}{*}{$\begin{array}{c}\text { P Value } \\
\text { Chi- } \\
\text { square }\end{array}$} & \multirow{3}{*}{$\mathbf{R R}$} & \multirow{3}{*}{$95 \% \mathrm{CI}$} \\
\hline & Constant & Descend & & & \\
\hline & $\mathbf{n}$ & $\mathbf{n}$ & & & \\
\hline Age & & & 1.000 & 1.385 & $0.095-20.16$ \\
\hline$\geq 45$ years & 1 & 12 & & & \\
\hline$<45$ years & 1 & 17 & & & \\
\hline Education & & & 1.000 & 0.926 & $0.832-1.030$ \\
\hline Low & 2 & 25 & & & \\
\hline High & 0 & 4 & & & \\
\hline \multicolumn{2}{|l|}{ Working Period } & & 1.000 & 0.813 & $0.046-14.28$ \\
\hline$>10$ years & 1 & 13 & & & \\
\hline $1-10$ years & 1 & 16 & & & \\
\hline Exercise & & & 1.000 & 0.929 & $0.838-1.029$ \\
\hline No & 2 & 26 & & & \\
\hline Yes & 0 & 3 & & & \\
\hline Training & & & 1.000 & 0.917 & $0.813-1.034$ \\
\hline No & 2 & 7 & & & \\
\hline Yes & 0 & 22 & & & \\
\hline \multicolumn{2}{|c|}{ Length of Working } & & 0.355 & 0.912 & $0.255-90.29$ \\
\hline$>40 \mathrm{hr} /$ week & 1 & 24 & & & \\
\hline $40 \mathrm{hr} /$ week & 1 & 5 & & & \\
\hline \multicolumn{3}{|c|}{ Frequency of Repetitive Movement } & 1.000 & 1.087 & $0.968-1.220$ \\
\hline Increase & 0 & 6 & & & \\
\hline Decrease & 2 & 23 & & & \\
\hline
\end{tabular}

As well as exercise that showed no significant correlation with the scale of hand pain reduction, workers who exercise less $(9.7 \%)$ than those who do not exercise. Worker training also showed a meaningless result, this is because the number of respondents who participated in job training was less (22.6\%), according to table 1 . The working period indicates a meaningless result, this was different from the literature. The 
difference can be explained by the process of making chips is a process of skill, where if these skills are increasingly being made it will be more skilled workers, so that the time required for making chips are also faster, so the time to be exposed to the movement and position while working on the wane .

Frequency of repetitive movement showed a nonsignificant correlation with the scale of decreased hand pain $(\mathrm{p}$ $=1,000)$. Although statistically not significant but based on the percentage of decreased scale of hand pain on the frequency of repetitive movement is reduced compared with the frequency of repetitive movement is increased. The possibility of repetitive causes was meaningless since the beginning of the repetitive movement that occurred before the intervention has exceeded its normal limit, so that despite the reduction in the frequency of repetitive movements it still has not reached the normal value for repetitive movement allowed.

Risk factors wrist flexion extension $\geq 20^{\circ}$, based on the theory that not a neutral hand position (awkward postures) raises the pressure and muscle contractions are prolonged without any time for relaxation, thereby inhibiting the flow of blood into the cells. If this happens continuously it will cause fatigue and end with the onset of musculoskeletal disorders. Contraction movements due to extension flexion will stretch and lengthen the tendon, so that the tendon can tear or slip from its attachment due to prolonged mechanical trauma. The existence of intervention pestle causing flexion wrist extension becomes non-existent. Because the work process using pestle different from the work process using hammer. With a pestle process flexion extension only occurs on the elbows, the removal of the fulcrum at the elbow by reason of muscles - the muscles in the forearm and upper arm through the elbow has a period greater muscle mass, so it is expected to be able to withstand the workload due to the flexion - extension elbow, so that the likelihood of musculoskeletal disorders compared with fewer wrists. This causes the avoidance of hand pain due to mechanical or vascular disorders that often cause the occurrence of pain [17,22,24].

\section{CONCLUSION}

The hypothesis proved that there was a decrease in hand pain after intervention with pestle for fourteen days compared with before intervention ( $\mathrm{p}=0.000$ : 95\% CI $=1.07$ - 1.72). There is no significant correlation between sociodemographic factors and occupation with decreased hand pain.

\section{REFERENCES}

[1] Media Indonesia. Depperin Tetapkan Emping Melinjo Makanan Khas Pandeglang.Dikutip pada 8/11/2009. http:// www.mediaindonesia.com/read/ 2009.

[2] Pelita.Banten Ekspor 500 Ton Emping Melinjo.Dikutip pada 12/12/2012. http://www.pelita.or.id/baca.php?id=81094

[3] Kompas.com.Pandeglang Sudah Eksport Emping Melinjo. Dikutip pada 6/11/2009.http//www.Kompas.Com

[4] Winzeler S,Rosenstein DB.Occupational Injury And Illness Of The Thumb Causes and Solutions.Journal AAOHN, vol. 44 p. 10, 1996.

[5] Departemen Kesehatan RI. Direktorat Bina Kesehatan Kerja. Pedoman Tatalaksana Penyakit Akibat Kerja Bagi Petugas Kesehatan.Penyakit Otot Rangka akibat Kerja. 2007.
[6] Departemen Kesehatan RI. Direktorat Bina Kesehatan Kerja,Direktorat Jenderal Bina Kesehatan Masyarakat. Strategi Nasional Kesehatan Kerja Di Indonesia. Jakarta. 2007

[7] W. Riyadina, FX. Suharyanto, L. Tana. "Muskuloskeletal pain among industrial workers in pulogadung Industrial estate Jakarta". Majalah Kedokteran Indonesia, vol. 58 Jan(1), 2008.

[8] J. Sim, RJ. Lacey, M. Lewis. "The impact of workplace risk factors on the occurrence of neck and upper limb pain: a general population study.BMC Public Health, vol. 19;6 p. 234, Sept 2006.

[9] F. William. "Ganong. Buku ajar fisiologi kedokteran”, Ed. 17. Jakarta 1999 .

[10] A. Sylvia, "Price.Konsep klinis proses - proses penyakit". Vol. 2. Ed. 6. Jakarta 2006

[11] A. Tamsuri, "Konsep dan penatalaksanaan nyeri". EGC: Jakarta. 2007

[12] Guyton.Fisiologi manusia dan mekanisme penyakit. Ed. 3. V.jakarta 1996

[13] Sobotta. "Tabel otot, sendi, dan syaraf". Ed. 22. EGC, Jakarta 2006

[14] D Sabiston, "Buku Ajar Bedah Bagian 2". Jakarta:EGC. 2010

[15] R. Sjamsuhidayat, Wim de Jong: Buku Ajar Ilmu Bedah. Edisi Revisi. Cetakan ke-3.Jakarta:EGC.2005

[16] Buckle PW, Devereux JJ. The nature of work related neck and upper limb musculoskeletal disorders. Appl Ergon. 2002; May; 33 (3):207-17

[17] Staal JB, de Bie RA, Hendriks EJ. Aetiology and management of work related upper extremity disorders. Best Pract res Clin Rheumatol.2007 Feb 21; 21(1):123-33

[18] Baktiansyah A. Buku Pegangan untuk PBL Penyakit Akibat Kerja. Edisi 1. Fakultas Kedokteran dan Kesehatan Universitas Muhammadiyah Jakarta, 2010.

[19] Humantech, Applied ergonomic training manual. 2nd Edition. Humantech Inc. 1995.p 225 - 300

[20] Fine J, Laurence, Silverstein. Work related disorders of neck and upper extremities. In : Levy BS Wegman DH,Editors. Occupational health recognizing ang preventing work related disease. $4^{\text {th }}$ ed. Philadelpia: Lippincott williams \& Wilkins;2000.p.195-209,503-535.

[21] NIOSH. Appendix B of "Musculoskeletal disorders and workplace factors ; A critical review of epidemiologic evidence for work - related musculoskeletal disorders of the neck, upper extremity,and low back".1997.available at http://lobby.la.psu.edu/062 Ergonomics Standarts/Agency Activities/OSHA/OSHA Health Chapterone.htm

[22] Vibration exposure assesment for industrial power tools.A pocket guide based on the physical agents (vibration) directive.www.atlascopco.se

[23] Cameron R.John, Skofronick G.James, Grant M.Roderick. Fisika Tubuh Manusia. Edisi 2.Cetakan1. EGC, Jakarta 2006

[24] Gabriel J.F. Fisika Kedokteran.Cetakan ke VII. EGC, Jakarta 1996 